\title{
Approaching Localized Politics of European Memories
}

\section{Salmi-Niklander, Kirsti}

Amsterdam University Press

2022

Salmi-Niklander , K , Laine , S , Salmesvuori , P , Savolainen , U \& Taavetti , R 2022 , Approaching Localized Politics of European Memories . in K Salmi-Niklander, S Laine , P Salmesvuori , U Savolainen \& R Taavetti (eds) , Friction, Fragmentation, and Diversity : Localized Politics of European Memories . Heritage and Memory Studies , Amsterdam pÿUniversity Press , Amsterdam , pp. 923.

http://hdl.handle.net/10138/340258

unspecified

acceptedVersion

Downloaded from Helda, University of Helsinki institutional repository.

This is an electronic reprint of the original article.

This reprint may differ from the original in pagination and typographic detail.

Please cite the original version. 
[This is the authors' peer-reviewed and accepted article manuscript included in Friction, Fragmentation, and Diversity: Localized Politics of European Memory (eds. Salmi-Niklander, K. et al.) published by the Amsterdam University Press in 2022. All rights in this article are reserved and its further distribution is prohibited.]

Full reference: Salmi-Niklander, K. \& Savolainen, U. \& Taavetti, R. \& Laine, S. Salmesvuori, P. 2022: "Approaching Localized Politics of European Memories." In: Friction, Fragmentation, and Diversity: Approaching Localized Politics of Memory (eds. Niklander, K. \& Laine, S. \& Salmesvuori, P. \& Savolainen, U. \& Taavetti R.). Memory and Heritage Studies. Amsterdam: Amsterdam University Press. Pp. 9-23. https://doi.org/10.2307/j.ctv25wxbrw.10

\section{Approaching Localized Politics of European Memories}

Kirsti Salmi-Niklander, Ulla Savolainen, Riikka Taavetti, Sofia Laine \& Päivi Salmesvuori

\section{Introduction}

During the past four decades memory has probably become the most influential and widely adopted term to describe the complex of temporal, ethical, aesthetic, intellectual, material, and political manifestations and uses of the past in present. This collection focuses on localized politics of memories in various European contexts. It will attend to diverse memories related to the historical events and time periods in Estonia, Russia, Latvia, Finland, Germany, and Turkey by focusing on the interplay, tension, and negotiation between various scales of memory (see De Cesari \& Rigney 2014).

The term "politics of memory" often refers to the quiddity and instrumentality of memory. Jan Kubik and Michael Bernhard (2014) argue that a political science interpretation of the politics of memory is limited to the analysis of deliberate actions to make us remember in a certain way. Emphasized here is the manipulation of memory, particularly by states and other official actors. (For a discussion of Kubik and Bernhard's model from a Baltic perspective in particular, see Pettai 2016.) In an introduction to politics of memory and life writing in Eastern Europe, Simona Mitroiu $(2015,8,16)$ argues that the concept of memory politics refers to state involvement in analyzing and preserving the past, as well as to systems of justice and "political responsibility for the past."

In this volume, however, we understand the concept of politics more broadly. In our utilization, "politics" in "politics of memory" refers to politicization, of becoming political and contested. In relation to memory, this politicization means that the past is opened as debated (Palonen 2003). 
These competing interpretations of the past also have political connotations for struggles over possible futures. Processes of politicization occur on different levels, from everyday interaction and diverse cultural representations to politics of the archive and politics as legal processes. In the chapters included in the present volume, the politicization of memories takes place on multiple analytical levels: those inherent to the sources; how the collections utilized, archived, or presented are gathered; and those involved with re-evaluating existing research. Moreover, politics of memory is the topic of study in a number of the analyses that address the processes of remembering, how memories become contested, and how they are debated in different contexts and between various scales.

While memory studies has developed into a thriving multidisciplinary field of scholarly discussion since the beginning of the so-called "memory boom" after the 1980s (see, e.g. Winter 2006), the concept of "politics of memory" has been more of a popular concept rather than one receiving focused academic attention. Politics of memory has been utilized as a practical and inclusive shorthand for the various ways in which representations of the past influence the present, as well as for the ways in which the past is used, created, and referred to in various social and political contexts in order to achieve something in the present. Due to its inclusive and flexible quality and the opportunities it offers to combine diverse approaches toward memories that originate from different national and discipline-based understandings, the term "politics of memory" is also at the center of this collection. We perceive politics of memory as a concept that allows analyzing memories on personal, group-level, national and transnational scales. Moreover, the concept enables scrutinizing the contrasting, contested, or sometimes even conflicting interpretations of the past that the individuals or communities may hold (e.g. Bell 2006).

This collection continues the discussion with regard to the dynamics of memory between various scales (e.g. Rothberg 2009; De Cesari \& Rigney 2014). As Chiara De Cesari and Ann Rigney (2014) have noted, the field of memory studies tends to implicitly assume hierarchical relations between diverse scales of memory. On the one hand, individual, local, and "grassroots" memories are considered as small-scale and highly specialized or particular and often heterogeneous memories. On the other hand, collective, public, official, and global memories, are perceived as homogeneous and broader configurations that inevitably operate as umbrellas for the heterogeneous set of individual memories on various grassroots localities. De Cesari and Rigney argue that analysis and critical rethinking of scales of memory enable theorizing the dynamics of memory beyond these spatial trajectories as a process that takes place in the dynamic interplay between 
scales and at their intersections. In what follows, we approach the localized politics of memories as well as dynamics of memory between various scales through the concepts of diversity, friction, and fragmentation.

\section{Diversity}

Memory plays a crucially important role in the identity processes of both individuals and communities. The selection, cultivation, manipulation, and presentation of elements of the relevant past through various mnemonic practices participate in a making of the present and the future. In the modern period, one of the most significant and self-evident frameworks for mnemonic practices and identity formations has been the trope of the "national." (See, e.g. Bell 2006.) Through practices more often naturalized than not, individuals and communities_-including scholarly ones-have built their understandings of the past on the basis of the image of nation as a territorially, ethnically, and culturally bounded entity.

Since the 1980s, questioning of the self-evident nature of national frames has become the new norm, at least among academia in the West. Indeed, new communication technologies and global capitalism have made the national framework redundant in many ways, and large-scale migration, both voluntary and forced, has undermined its entitlement and naturalness. In the field of memory studies as well, a strong critique of methodological nationalism (e.g. Wimmer \& Glick Schiller 2002) has been accompanied by the turn toward the "transnational" and "transcultural." Instead of analyzing memory with regard to national frameworks, the focus of analysis has shifted to the dynamics between various frameworks of memory and to the movement of memory (see, e.g., Rothberg 2009; Erll \& Rigney 2009; Assmann \& Conrad 2010; Erll 2011; Bond \& Rapson 2014; De Cesari \& Rigney 2014; Bond, Craps, \& Vermeulen 2017; Erll \& Rigney 2018).

With this transnational turn as a backdrop, the analytical focus of the present collection is more clearly targeted toward different national contexts and intersections of various other categories with the national in them. We call for an understanding of the national not as a framework of memory that is bounded and stable - let alone somehow more natural than others - but as a problematized category that is overlapping with several other categories. Memories, understood as (re)mediated "texts" (incorporating various kinds of cultural modalities and forms besides written texts), indeed circulate (Rigney 2005), travel (Erll 2011), and exist multidirectionally (Rothberg 2009) across and between national as well as other kinds of borders and scales, and the idea of nation as an imagined 
and socially as well as politically constructed community (Anderson 1983) is widely accepted among academia. That said, the national still remains as one of the important frameworks according to which various pasts as well as their relevance with regard to the present and future are negotiated. Moreover, the concept of politics of memory is typically utilized when addressing conflicts over representations of the past by dominant and subordinate groups in a certain society (e.g., de Grua 2016), often conceived as national. In the chapters of the collection, the national is presented and discussed in relation to a diversity of adjacent, opposing, and intersecting categories such as religion, ethnicity, gender, and sexuality, as well as between individual, group, local, transnational, and global scales.

Geographically speaking, the emphasis of the collection is on local contexts in different parts of Europe. Indeed, most of the cases discussed are located to Europe's east. Overall, however, the chapters form a highly heterogeneous range of studies focusing on diverse historical, political, and geographical contexts. Therefore, we call for nuanced localization when addressing memory cultures. As stated earlier, the focus on transnationality and the dynamics of memories across national borders and between various categories should not entail that localized specificities are forgotten or bypassed, but on the contrary. We emphasize the importance of careful temporal and spatial contextualization when addressing the diversity of memories and memory cultures, as well various scales connected to them.

Even though the definition of a clear temporal focus is always difficult when discussing memory and memories, the general time span of the chapters extends from the Second World War to the present. We acknowledge, however, that memories are not limited to this period but echo layers of earlier remembrances and histories. Whilst the aftermath of the Second World War is reflected in all of the cases in one way or another, none of the chapters has the memory of the Holocaust as its primary focus, even as the Holocaust has often been conceived as the heart of the study of cultural memory in Europe (e.g. Bell 2006). Especially in the context of the Baltic states, the memory of the Holocaust is discussed as a contrast to the memory of the Soviet and other state-socialist repressions (see especially Kõresaar \& Jõesalu and Radzobe \& Bērziņš). In fact, many of the cases discuss the borders between East and West, and sometimes the borders of Europe. We believe that this diversity in the case studies not only justifies but also requires turning the focus from memory alone to the plurality of memories and memory cultures. Indeed, the chapters in this collection reflect a range of political, societal, and cultural contexts which also have an effect on the expressions and practices of remembrance. 


\section{Friction}

The chapters of this collection discuss case studies that reflect different local contexts in terms of political, societal, and cultural frameworks as well as different understandings of the qualities, roles, and functions of the past in present. Even though memory always has a political dimension, we can safely say that "politics of memory" finds its expression in different ways in democratic societies on the one hand and authoritarian societies on the other. Also, the possibilities to critique and deconstruct memory vary, depending on a society's political system. That said, rather than evaluating divergent memory cultures on normative scales of democratic and authoritarian, free and restricted, or healthy and pathological, an analytically more fruitful approach would be perhaps to turn the focus to the differences of memory cultures and the entailing regimes or ideologies of memory (see Radstone \& Hodgkin 2003; Savolainen, forthcoming), as well as to the negotiations and frictions that occur when these different ideologies collide. Compared to the memory cultures of Russia and Turkey, for example, the memory cultures of the so-called democratic West might appear to us as more permissive.

Yet, even though corollaries of the countering of the official or hegemonic memory might not be as severe in democratic societies as they may seem in more authoritarian ones, we should remain critical with respect to the assumed permissiveness of Western memory cultures, not to mention the assumed universality of Western ideas with regard to memory. Analyzing global connections and how values and norms considered as universal are received by local communities, anthropologist Anna Lowenhaupt Tsing (2005) coins the term "friction" to illustrate diverse and conflicting social engagements that produce the global world. Applying Tsing's metaphor, Rosalind Shaw (2007) introduces the concept of "memory friction" to describe productive tensions that occur when culture-dependent ideologies, practices, and mechanisms of dealing with the past—considered as "universals"- are transported to another cultural context. Shaw's ethnographic case study concerns the frictions that emerged when the Truth and Reconciliation Commission of Sierra Leone, which was based on the Western idea of redemptive remembering and the healing power of truth-telling, engaged with local understandings of the best practices of dealing with a difficult past, themselves based on ideas of forgetting and conscious silencing (see also Kennedy 2018). Universal memory pure of cultural values, ideologies, and politics is non-existent. This means that local regimes of memory are different, and so are their influence and authority. 
In terms of friction, the concepts of "trauma" and "reconciliation" as well as the ways in which they are discussed in several chapters of this collection (Savolainen; Selyaninova; Kucheva) serve as prominent examples. As several scholars (e.g., Radstone 2007; Craps 2013; Kennedy 2018; Bell 2006; Rigney 2018; 2020) have noted, multiple problems and peculiarities point to "trauma" as a phenomenon and analytical concept and to trauma theory as a methodological apparatus. In addition to obvious problems with the term, which stem from Western-centric premises (see Craps 2013), "trauma" easily adapts as a flexible concept with the power to explain various phenomena being either a result or a manifestation of trauma. It may also lead to the creation of unproblematized parallels between the operations of individual cognition or the psyche and societal and political processes of managing the past. The hegemonic position of trauma as an explanation of memory and forgetting may also lead to simplification of various and culture-specific mechanisms related to remembering and forgetting. At the same time, in many cases the relativist reframing of "trauma" as a "merely" social construction or dismissing it altogether may come across as an arrogant and unethical standpoint. In addition to explaining the influence of a fearsome past in the present, "trauma" can also serve as a frame that enables discussion of difficult memories and contested histories. Moreover, "trauma" may also function as a powerful label with the potential to provide previously overlooked memories or ignored perspectives with relevance.

In memory discourse, the concept of "reconciliation" connects to discussions about the aftermath of various societal upheavals at the time of transition. "Reconciliation" is then often framed as a method for achieving societal stability and justice as a condition of a brighter future and as an alternative to continuing instability, chaos, and inequity. Without questioning the desirability of these goals in any way, positing "reconciliation" as the key for peace and justice nonetheless calls for critical consideration. In fact, a too straightforward and totalizing pursuit for reconciliation may lead to an ignoring of non-conciliatory experiences and viewpoints and a loss of the productive potential of these critical voices (see also Rigney 2012; Savolainen 2018; 2020). Indeed, when embraced uncritically, rather than being a method of justice and hope, "reconciliation" may turn into a restrictive, normative, and controlling regime of memory.

In many ways, this collection is a frictional site representing various memory ideologies. By ideology, we do not refer to coherent and systematic political doctrine. Instead, memory ideology refers to any collection of theories, beliefs, assumptions, and feelings concerning the role of the past with respect to the present (see Savolainen, forthcoming). Instead of curbing either the more 
normative or the more relativist perspectives, we have chosen to incorporate them in this collection in order to showcase the diversity of the analytical approaches with regard to memories.

\section{Fragmentation}

This collection continues the discussion on the interplay of scales of memory (De Cesari \& Rigney 2014). The contributions all discuss the interplay of various scales, but the overall emphasis of the collection is on the memories and perspectives of individuals and local communities as well as their relations, tensions, and interplay vis-à-vis the collective, public, or official dimensions of memory. This focus is manifested in the contributions primarily through the strong emphasis on the interview materials, namely oral history interviews as objects of analysis. As products of communicative and interpersonal contact, interviews mediate individuals' memories and experiences as well as views and understandings of the past in the present. However, as already noted by Maurice Halbwachs (1992), individuals' memories cannot be separated from social, collective, or public memory.

Many of the investigations in this collection (Daphi \& Zimmerman; Savolainen; Selyaninova) utilized oral history interviews emphasizing the multiplicity and possible contradictory nature of personal memories. As a field, oral history research has dedicated itself to the analysis of individual voices and memories of laypeople from the 1940s on (Perks \& Thomson 2016; Abrams 2016). Despite extensive amounts of research of oral recordings, narratives, and histories related to various historical events in various contexts, as a research branch oral history has to some extent suffered from excessive descriptiveness, lack of theoretical rigor, and sometimes even naïvely positivistic persuasions. Indeed, the field has to some extent downplayed the role of cultural frames and patterns that guide individual representation of personal experience and link it together with the cultural (Hamilton \& Shopes 2008). Further still, although the field has produced a significant body of practical methodological knowledge on interviewing techniques (see e.g. Thompson \& Bornat 2017 [1978]; Ritchie 2003; Yow 2005), the predefined principle to focus only on interviewing and audio recordings has hampered the successful fulfillment of one of the main missions of the field the aim to understand and acknowledge people's memories and various practices of memory and history production. Quite obviously, these are not only represented orally.

The Nordic and Baltic field of oral history research, however, forms a somewhat different domain. Investigation of reminiscence writings, autobiographies, and other forms of written remembering in addition to recorded interviews from the methodological perspectives of oral history research 
characterize the Nordic and Baltic field of oral history research. A departure from strictly oral materials has indeed led to fruitful methodological and theoretical discussions within the field (see, e.g., Fingerroos \& Haanpää 2012; Heimo 2016; 2017). Moreover, internationally speaking, while cultural memory studies and oral history research have largely developed separately (Hamilton \& Shopes 2008), in the Nordic and Baltic academic context these approaches have been entangled (Heimo 2016; 2017; Kõresaar 2016; Kõresaar \& Jõesalu 2016; Kuusisto-Arponen \& Savolainen 2016; Savolainen 2017; 2020; Taavetti 2018). In many ways the current collection stems from this entangled field. Moreover, in the context of post-authoritarian societies, personal memories have formed an essential aspect of building the national past. For example, after the restoration of independence in the Baltic states in the early 1990s, national histories have been built on the compilation of written life stories and oral histories (on the case of Estonia, see Kõresaar \& Jõesalu 2016). These developments illustrate the intertwined nature of the various scales of remembering, which we take as a point of departure in this collection.

A shared starting point of the contributions included in this collection is that various scales of memory are inherently connected together and exist only through their mutual relationship, even if a conflicted one. We however want to point out that this does not mean bypassing any of the scales, quite the opposite. Instead, we want to highlight that the deep understanding of multi-scalar dynamics of memory necessitates paying careful and close attention to the specificities of each localized context. It also entails accepting that memory cultures may appear to be highly fragmentary conglomerations with various incommensurate dimensions. Thus, in order to take into account the fragmentary nature of local memory cultures, instead of referring to "memory" in the singular in the title, we have chosen to discuss "memories" in the plural. By resisting and evaluating the appeal to move toward the ideals of coherence and uniformity, we hope that this collection functions as a critical contribution to inquiries focusing on various localized memories and their dynamics vis-à-vis multiple scales. We address remembering and its political dimensions as dynamic processes in which memories are created in the interplay between the individual, the collective as well as local, (trans)national, and global dimensions and various social and political formations.

\section{Chapters in the Collection}

The book consists of two parts. The chapters in the first part tackle the issues of politicized memories and pasts in Estonian, German, Russian, and Latvian contexts. Kirsti Jõesalu and Ene 
Kõresaar explore the public reception to a recent attempt of the Estonian Museum of Occupations to omit the term "occupation" from its name. The theoretical background is the politics of naming, which provides possibilities for discussing the various scales of memory. Renaming of the museum invoked a debate in Estonian society, which reflected a tension and a clash between national and cosmopolitan memory. In particular, replacement of "occupation" with "freedom" was interpreted as a shift from a national to a Russian interpretation of memory. Moreover, as the authors argue, the debate manifested a deep interconnectedness of the scales of individual, cultural, private, public, and political remembering in contemporary Estonia. Their conclusion is that Estonian society insists on holding on to national interpretations of the difficult past rather than opening up to new perspectives.

The contribution by Priska Daphi and Jens Zimmerman also attends to politics of memory by examining the tension and negotiation between activists' memories and public memories around the "68 movement" in Germany. This period of violence and civil disobedience still constitutes a controversial issue in German public discourse. The chapter focuses on the memory culture of the German Occupy movement (2011-2016), and activists' memories and reflections are compared with media analysis. In the chapter, the relation between these scales of activists' memories and public memories is conceptualized through the notion of counter-memory that implies the presence of multiple interpretations of the past that might also be mutually competing and opposite. Their conclusion is that the Occupy activists share a partial counter-memory of ' 68 .

Riikka Taavetti's chapter addresses the localized politics of memories by analyzing queer memories in Estonian present-day discussion. She examines an art exhibition by the contemporary Estonian artist Jaanus Samma, titled "Not Suitable For Work. A Chairman's Tale," based on the life story of a Soviet Estonian man who was prosecuted in the mid-1960s for homosexual acts. Taavetti analyzes the reception to two presentations of this exhibition, first at the Estonian Pavilion at the Venice Biennale in 2015, and later at the Museum of Occupations in Tallinn in 2016. These contexts framed the exhibition with questions of victimhood from different angles: namely, human rights violations of people persecuted because of their sexuality and Soviet repression in Estonia. Taavetti's chapter exposes the dynamic interaction of various divergent spatial, temporal, and interpretive frames in the formation of memories and interpretations of the past.

The fourth chapter focuses on post-Soviet Latvia. The authors, Laura Ardava and Jurijs Nikišins examine the diversity of social memories of transformative events, analyzing their ethnic and 
generational dimensions. They question how social memories manifest themselves in Latvian society across age and ethnic groups. The authors provide a comparison of social memories across major ethnic and generational groups, drawing on evidence from recent national surveys. They also touch on the attribution of memory conflicts to the media space in Latvia, as well as Russia's impact on it. In the conclusion, Ardava and N̦ikišins discuss the possible future dynamics of social memories and their implications for the coexistence of diverse social memory groups within Latvia. They conclude that nearly three decades after the fall of the Soviet Union, profound opinion cleavages are still persistent, revealed as differences in value judgments about major historical events of the 20th century that had a transformative effect on Latvian society and are manifest across generations, as various age groups choose different events as the "worst" or the "best" ones.

By means of oral history, Gulsina Selyaninova investigates the sociocultural trauma resulting from repressions associated with the "Anti-Soviet Ishanism Establishment Case" of 1948 in the Perm region (Soviet Union). She investigates Muslims who had been sentenced as Ishanism devotees before, during, and after the Gulag. Oral interviews allowed the lives of the arrested people to be traced, but also those of their families and people who were more or less close to them. The chapter confirms the fact that the Muslims arrested in 1948 were indeed followers of the tradition of Ishanism. The study identifies how the society-and ishans and murids themselves-managed to adapt to the consequences of the arrests and demonstrates how silences work in diverse scales in the process of remembering and negotiating a difficult past.

The concepts of friction and diversity unite the chapters of the second part. Geographically, the cases cover Finland after the Second World War, the Soviet Union before and after the war, and contemporary Turkey and Latvia. Ulla Savolainen approaches the reception of the compensation law for the internment of German and Hungarian citizens in Finland (1944-1946) from the perspective of oral history interviews of former child and youth internees. The interviews are analyzed in relation to and as reflecting the wider framework of cultural memory, namely the paradigm of redemptive remembering. With attention to methodological sensitivity, Savolainen argues that the interaction between interviewer and interviewees can be characterized as negotiations about the aims of the interview. She claims that victims' dissatisfaction with the compensation law can stem from a sense of being excluded from the processes of how the law was defined rather than from its contents per se. Savolainen's contribution demonstrates the frictions involved in the processes of compensating past injustices. 
Anna Koldushko considers the problems of sociocultural trauma caused by the repressions of the 1930s in the Urals. According to Koldushko, the traumatic experience of the repressions was characterized as a personal trauma. The motivation for analyzing the traumatic experience of the Stalinist repressions is born out of the necessity to explain the individualization of this trauma and to address the problem of commemorative practices of Soviet society. She discovers the elements of experience of frictional justice in the insufficient degree of reflection on the trauma by both the victims and their relatives. The chapter employs a narrative approach, which allows diagnosis of the main components of the trauma.

In Turkey, the lack of resolution of the "Kurdish question" for more than thirty years has been a major source of grievance affecting the lives of many, particularly women. The chapter, written by Serpil Açıkalın Erkorkmaz and Dilek Karal, focuses on the fragmented cultural memories of women in Turkey on the Kurdish issue. The authors examine the patriarchal character of Turkish modernization and the construction of women's identities, and they seek the historical roots of social schisms among women in Turkey. The authors analyze how women's cultural memories shape their perception of "threat" regarding the Kurdish issue. The authors contend that identity as a composition of ideological, religious, and ethnic differences is the major determinant of women's segmented cultural memories in Turkey on the Kurdish issue and gender roles. These differences also affect an individual's perception of threats from other social groups in society.

Anastasia Kucheva looks into the diversities of survival strategies in postwar everyday life in Soviet society. Kucheva considers the Second World War and its impact on Soviet society within the framework of the currently relevant problem of cultural trauma. The novelty of the study is how it changes the prospects of studying the consequences of the Second World War for Soviet society. Analysis of archive materials and interviews collected by the author made it possible to reconstruct the everyday life of Soviet people. Kucheva studies adaptation models formed in such spheres of life as procuring food, non-food items, and accommodation. Kucheva analyzes reflections on the war experience, revealing how the people who survived the war have perceived the influence of certain experiences on their present lives.

The concluding chapter, authored by Zane Radzobe and Didzis Bērziņš, explores the memory diversity of Latvians and Russian speakers in Latvia in the $20^{\text {th }}$ century. The research deals with memory policies and the practices of the groups, drawing conclusions on how the ritualization of memories is used to establish competing discourses of national history and identity. The ritualistic 
practices of memory are analyzed as a chain of counter-memory practices. The authors conclude that resistance against the official discourse of history is an ongoing process. 


\section{References}

Abrams, Lynn. Oral History Theory. Second edition. Abingdon, Oxon: Routledge, 2016.

Anderson, Benedict. Imagined Communities: Reflections on the Origin and Spread of Nationalism. London: Verso, 1983.

Assmann, Aleida \& Sebastian Conrad (eds.) Memory in a Global Age: Discourses, Practices and Trajectories. London: Palgrave Macmillan, 2010.

Bell, Duncan. "Introduction: Memory, Trauma and World Politics." Memory, Trauma and World Politics: Reflections on the Relationship between Past and Present. Ed. Duncan Bell. Basingstoke; New York: Palgrave Macmillan, 2006. 1-29.

Bond, Lucy \& Jessica Rapson (eds.) The Transcultural Turn: Interrogating Memory between and beyond Borders. Berlin: De Gruyter, 2014.

Bond, Lucy, Stef Craps \& Pieter Vermeulen (eds.) Memory Unbound: Tracing the Dynamics of Memory Studies. Oxford: Berghahn, 2017.

Craps, Stef. "Beyond Eurocentrism: Trauma Theory in the Global Age." The Future of Trauma Theory. Contemporary Literary and Cultural Criticism. Eds. Gert Buelens, Samuel Durrant \& Robert Eaglestone. London \& New York: Routledge 2013. 45-61.

De Cesari, Chiara \& Ann Rigney (eds.) Transnational Memory: Circulation, Articulation, Scales. Berlin: De Gruyter, 2014.

De Grua, David W. Surviving Wounded Knee: The Lakotas and the Politics of Memory. Oxford: Oxford University Press, 2016.

Erll, Astrid. "Travelling memory.” Parallax 17.4 (2011): 4-18.

Erll, Astrid \& Ann Rigney. Mediation, Remediation, and the Dynamics of Cultural Memory. Berlin: De Gruyter, 2009.

Erll, Astrid \& Ann Rigney (eds.). Special Issue: Cultural Memory Studies after the Transnational Turn. Memory Studies 11.3 (2018).

Fingerroos, Outi \& Riina Haanpää. "Fundamental Issues in Finnish Oral History Studies.” Oral History 40.2 (2012): 81-92.

Halbwachs, Maurice. On Collective Memory. The Heritage of Sociology. Chicago: University of Chicago Press, 1992.

Hamilton, Paula \& Linda Shopes. "Introduction: Building partnership between oral history and memory studies." Oral History and Public Memories. Eds. Paula Hamilton \& Linda Shopes. Philadelphia: Temple University Press, 2008. vii-xvii.

Heimo, Anne. "Nordic-Baltic Oral History on the Move." Oral History 44.2 (2016): 37-58. 
Heimo, Anne. "The Italian Hall Tragedy, 1913. A Hundred Years of Remediated Memories." The Twentieth Century in European Memory. Transcultural Mediation and Reception. Eds. Barbara Törnquist-Plewa \& Tea Sindbæk Andersen. Leiden: Brill, 2017. 240-267.

Kennedy, Rosanne. "Reparative Transnationalism: The Friction and Fiction of Remembering in Sierra Leone.” Memory Studies 11.3 (2018): 342-354.

Kõresaar, Ene. "Life Story as Cultural Memory: Making and Mediating Baltic Socialism since 1989.” Journal of Baltic Studies 47.4 (2016): 431-449.

Kõresaar, Ene \& Kirsti Jõesalu. "Post-Soviet Memories and 'Memory Shifts' in Estonia." Oral History 44.2 (2016): 47-58.

Kubik, Jan \& Michael Bernhard. "A Theory of the Politics of Memory." Twenty Years After Communism: The Politics of Memory and Commemoration. Eds. Michael Bernhard \& Jan Kubik. Oxford \& New York: Oxford University Press, 2014. 7-34.

Kuusisto-Arponen, Anna-Kaisa \& Ulla Savolainen. "The Interplay of Memory and Matter: Narratives of Former Finnish Karelian Child Evacuees.” Oral History 44.2 (2016): 59-68.

Mitroiu, Simona. "Life Writing and Politics of Memory in Eastern Europe: Introduction." Life Writing and Politics of Memory in Eastern Europe. Ed. Simona Mitroiu. Basingstoke: Palgrave Macmillan, 2015. 1-22.

Palonen, Kari. "Four Times of Politics: Policy, Polity, Politicking, and Politicization." Alternatives 28.2 (2003): 171-186.

Perks, Robert \& Alistair Thomson. The Oral History Reader. Third edition. London: Routledge, 2016.

Pettai, Eva-Clarita. "Debating Baltic Memory Regimes.” Journal of Baltic Studies 47.2 (2016): $165-178$.

Radstone, Susannah. "Trauma Theory: Contexts, Politics, Ethics.” Paragraph: A Journal of Modern Critical Theory 30.1 (2007): 9-29.

Radstone, Susannah \& Katharine Hodgkin. "Regimes of Memory: An Introduction." Regimes of Memory. Eds Susannah Radstone \& Katharine Hodgkin. London \& New York: Routledge, 2003. 122.

Rigney, Ann. "Plenitude, scarcity and the circulation of cultural memory." Journal of European Studies 35.1 (2005): 11-28.

Rigney, Ann. "Reconciliation and remembering: (how) does it work?” Memory Studies 5.3 (2012): 251-258.

Rigney, Ann. "Remembering Hope: Transnational Activism Beyond the Traumatic." Memory Studies 11.3 (2018): 368-380.

Rigney, Ann. "Mediations of Outrage: How Violence Against Protestors is Remembered." Social Research: An International Quarterly 87.3 (2020): 707-733. 
Ritchie, Donald A. Doing Oral History: A Practical Guide. Oxford: Oxford University Press, 2003.

Rothberg, Michael. Multidirectional Memory: Remembering the Holocaust in the Age of Decolonization. Stanford: Stanford University Press, 2009.

Savolainen, Ulla. "Tellability, frame and silence: The emergence of internment memory." Narrative Inquiry 27.1 (2017): 24-46.

Savolainen, Ulla. "Miksi historian hyvitykset epäonnistuvat? Törmäävät muistikäsitykset ja hyvityksen moraali." Historiallinen aikakauskirja 116.1 (2018): 56-68.

Savolainen, Ulla. "Points and Poetics of Memory: (Retrospective) Justice in Oral History Interviews of Former Internees.” Memory Studies 13.6 (2020): 1020-1035.

Savolainen, Ulla. "Memory Ideologies of Two Presents: Aatami Kuortti's Testimonies of the Gulag and Soviet Terror of Ingrian Finns." Poetics Today (Forthcoming).

Shaw, Rosalind. "Memory Frictions: Localizing truth and Reconciliation in Sierra Leone." International Journal of Transitional Justice 1 (2007): 183-207.

Taavetti, Riikka. Queer Politics of Memory: Undisciplined Sexualities as Glimpses and Fragments in Finnish and Estonian Pasts. Helsinki: University of Helsinki, Faculty of Social Sciences, 2018.

Thompson, Paul \& Joanna Bornat. The Voice of the Past: Oral History. Fourth edition. New York: Oxford University Press, 2017.

Tsing, Anna Lowenhaupt. Friction: An Ethnography of Global Connection. Princeton, NJ:

Princeton University Press, 2005.

Wimmer, Andreas \& Nina Glick Schiller. "Methodological Nationalism and Beyond: Nation-State Building, Migration and the Social Sciences." Global Networks 2.4 (2002): 301-334.

Winter, Jay. "Notes on the Memory Boom: War, Remembrance and the Uses of the Past." Memory, Trauma and World Politics: Reflections on the Relationship between Past and Present. Ed. Duncan Bell. Basingstoke; New York: Palgrave Macmillan, 2006. 54-73.

Yow, Valerie Raleigh. Recording Oral History: A Guide for the Humanities and Social Sciences. Walnut Creek, CA: AltaMira Press, 2005. 